\title{
Formation of marketing clusters in the agro- industrial complex of Russia
}

\author{
Svetlana Ugrimova ${ }^{1, *}$, Tatiana Tukhkanen ${ }^{1}$, Natalya Andreeva ${ }^{2}$, and Mikhail Kabanenko ${ }^{3}$ \\ ${ }^{1}$ Don State Technical University, 1, Gagarin Sq., 344003, Rostov-on-Don, Russia \\ ${ }^{2}$ Rostov State University of Economics (RSUE), 69, B. Sadovaya St., 344002, Rostov-on-Don, Russia \\ ${ }^{3}$ Federal Rostov Agricultural Research Centre (FSBSI FRARC), Institutskaya str. 1, 346735, p. \\ Rassvet, Aksay district, Rostov region, Russia
}

\begin{abstract}
The topical theoretical issues along with the experience of establishment and functioning of clusters in the agro-industrial complex are analyzed in the article. The theoretical background of their formation and the system of basic concepts of marketing cluster operation in the agroindustrial complex are considered, economic benefits from its formation and expected challenges for cluster functioning are evaluated. The working-out of strategic areas for marketing clusters' formation in Russia is conducted in the article, which will enable the dynamic development of the country's economy in complex current conditions. Conceptually, the clustering of economy is based on a combination of national and regional interests and opportunities intended to strengthen the real sector and raise the population's living standards on this basis. The developed model of marketing cluster in the agro-industrial complex is presented and the principles of its creation and further functioning are described.
\end{abstract}

\section{Introduction}

Currently, the Russian Federation is going through a period of transition from the factorbased economy to the efficiency-oriented economy. Meanwhile, the middle level of economic development with raw-material orientation of the economy and low income levels of population and business is observed in the country. In addition, the problems include low efficiency of functioning of both state and market institutions, as well as a high degree of economy sluggishness in Russia.

The sluggishness of operation of most Russian enterprises including the agro-industrial complex is linked to, firstly, the lack of flexibility and timeliness of responses to market changes and, secondly, the non-conformity of enterprise management system with the challenges of our time. Consequently, Russia dropped from 45th to 50th place in the world competitiveness ranking of economies published by the International Institute for Management Development (IMD) [1].

In this regard, the question arises of searching for areas of enterprise competitiveness development through the management model change, the core of which is the transition from

\footnotetext{
* Corresponding author: s.ugrimova@yandex.ru
} 
traditional economic policy to modern management practices. These practices imply the generation of synergies by means of specialization, integration, and cooperation.

\section{Research methodology}

The research methodology is based on the system of fundamental and special scientific methods. The study of Russian and foreign experience of agricultural support relies on the system of principles (development, determinism, unity and distinction of studied processes and phenomena) and methods (observation, abstraction, synthesis, analysis, deduction, induction, comparison). The methods of contemporary economic theory (systems, evolutionary, institutional, and statistical analysis) were used for the study of state support of agricultural sector.

The information base of the research is represented by the official statistics of the Russian Federation and international organizations along with the findings of studies contained in monographs, articles of Russian and foreign economists, materials of periodicals.

The relevance of the topic depends on the general unsatisfactory functioning condition and the need to find ways to increase the efficiency and competitiveness of enterprises of the Russian agro-industrial complex. The problems of enterprise competitiveness development and economy integration by coordinating the efforts of its participants are widely covered in the works of Russian and foreign researchers. For instance, the problems of economy integration development based on the cluster strategy formation were discussed at different times in the works of scientists such as A.V. Babkin, M.A. Bushuev, K.A. Zagorodnikov, L.A. Karjakin, Y.N. Lapygin, O.A. Novikov.

The feasibility of establishing agro-industrial clusters is proved in the papers of researchers such as I.G. Alexandrova, N.N. Baransky, O.V. Bogdanova, D.V. Zavyalov, E.V. Ivanova, K.V. Milyaev, T. D. Nasrullaeva, V.I. Samarukha, E.V. Titova and others.

A significant contribution to the study of cluster inter-firm collaboration, in particular issues related to cluster institutional and financial support, was made by foreign scientists including K.A. Aziz, A.G. Granberg, D. Clarke, A. Malmberg, P. Maskell, M. Norhashim, M. Porter, A. Smith, D. Ricardo, S. Rosenfeld, E. Heckscher, R. Fischer.

However, despite the great scientific interest to cluster systems, they are examined fragmentarily and selectively, which forms an objective need to develop new theoretical generalizations and approaches to the solution of problems of enterprise competitiveness development and determination of development prospects for new economic and organizational structures of cluster type in the agro-industrial complex of Russia.

The purpose of the study is to summarize scientific advances and framework of categories, to analyze the structure and types of clusters, the feasibility, benefits, and theoretical aspects of marketing clusters' formation as well as the problems of their functioning in Russia.

\section{Results}

One of the most pressing issues for humanity is the problem of food security, which more and more countries face. According to the Food and Agriculture Organization of the United Nations (FAO), the population of more than 40 countries is experiencing food shortages, and more than 690 million people are starving in 2019 because of the sharp rise of food prices in the world [2].

The food shortage leads to higher food prices, and this, in turn, can be the cause of more severe consequences including threats to food security, spread of poverty, actual hunger, vulnerable segments of the population, and social unrest. According to the experts, Russia can provide food not only for its citizens, but also for another 600-700 million people [3, 4]. 
However, the efficient use of resources largely depends on the formation of new types of integration structures in the country's agro-industrial complex.

The key risks for agriculture in the world economy include the restrictions on international trade in agricultural products imposed by individual governments, certain logistics difficulties leading to the interruption of supply chains to end users, both in the external and domestic markets, as well as certain restrictions on mobility labor force employed in agriculture.

At the moment, many researchers see the formation of clusters as the only way to maintain enterprise competitiveness [5].

The concept of cluster is used in various business structures with different objectives to increase the competitiveness of enterprises of all forms of management, conduct scientific research, and protect the environment. Despite the existence of a considerable number of cluster definitions, most of them are linked to the concept of spatial proximity and industry specialization.

According to the concept of P. Maskell and A. Malmberg, regional clusters include many enterprises from related industries which are spatially limited.

S. Rosenfeld clearly pointed out that cluster formation requires active channels of business transactions and interaction.

M. Porter specified that a cluster or industrial group is a group of interconnected companies and related organizations operating in a chosen field, complementing each other and characterized by common activities. The relationship usually exists in a geographic area where communications, logistics, human resources are easily accessible. Clusters are generally located in regions and sometimes in a particular city.

Most researchers view cluster as a concentration of enterprises in a specific area which are connected by active business channels, communications, and logistics. These enterprises are connected by specialization, market and have similar problems and development prospects. Consequently, a cluster is a set of interrelated production, service and sales companies which includes suppliers, scientific organizations, market infrastructure and consumers [6].

The structure of the Russian agro-industrial complex, which was largely formed back in the USSR, for a long time did not fit into market conditions. The reorganization of collective and state farms, which took place in the 90s of the XX century, did not actually lead to qualitative changes of industrial relations in the agro-industrial complex, only the organizational and legal status of enterprises was changed [7].

Further changes led to the adaptation of Russian agriculture to market conditions, but high-cost traditional technologies related to the use of unskilled labor are still applied.

One of the weaknesses of the Russian agro-industrial complex includes different interests of enterprises of agricultural machinery industry, agriculture, and processing sector. Each of these branches of the agro-industrial complex is focused only on its own technological stage of the production of final product. Furthermore, toll processing arrangements are still practiced, which reduces production efficiency and leads to increased costs.

The specificity of the agro-industrial complex consists in the sustained dependence of its sectors in the process of production, where each sector is both a consumer and a producer of resources that will be consumed at the next production stage [8].

Under these circumstances, taking into account the uncoordinated and imbalanced sectors of the agro-industrial complex, agricultural and processing enterprises are unable to successfully compete on their own with food imports.

Therefore, it is the cluster that can be the optimal integration form of enterprises of various sectors of the agro-industrial complex connected by technological, financial, logistic and coordination processes. 
The factors motivating the integration of agricultural enterprises into the cluster include the following:

- efficient and coordinated interaction of sectors of the agro-industrial complex;

- agreed requirements of processing enterprises for suppliers of raw materials (varieties of seeds, growing season, etc.);

- increased opportunities for outsourcing, engineering and consulting for the production of final product;

- establishment of an integrated database on the market conditions and agricultural technologies' development;

- additional opportunities for attracting investments, including for small businesses;

- economy of scale enabling to reduce the expenditure on innovation;

- the possibility of exporting agricultural products and entering new markets.

The agro-industrial integration development at different times involved cluster formation on territorial and sectoral basis. This approach to cluster formation in the agro-industrial complex has both strengths and weaknesses.

The sectoral basis of cluster formation fully reflects the development of those agroindustrial enterprises that can carry out economic activities without reference to a certain territory or land area (poultry farming, vegetable growing, horticulture) $[9,10,11]$.

The territorial principle of cluster formation is largely due to the technological connection of a significant part of agricultural production with land resources.

At present, these two principles are combined due to theoretical developments and practical experience. Therefore, territorial and sectoral principles of cluster formation are widespread in the agro-industrial complex.

However, the process of territorial-sectoral cluster formation in the agro-industrial complex carried out in recent years is initiated "from above" in the sense of formal organization and is rather a project of the authorities of corresponding level [7].

Currently, in the process of cluster formation in the agro-industrial complex it is necessary to integrate not only agricultural and industrial capital, but also financial and commercial capital. At the same time, the imbalance in structure of the agro-industrial complex should be taken into account in the process of cluster formation. Agriculture is the leading sector of the agro-industrial complex, in which more than $50 \%$ of all agro-industrial products are made with a high level of labor intensity and energy intensity. However, the lead role in the agroindustrial complex of economically developed countries is played by the food industry and is associated with products' processing and sales [12].

In this regard, it is relevant to establish agro-industrial and agribusiness trade associations of closed cycle in the form of a marketing cluster that includes all stages of agricultural production: from production to sales of final product.

The marketing cluster implies integration of enterprises of "agricultural production processing - sale" chain. The model of suggested marketing cluster in the agro-industrial complex is shown in Figure 1. 


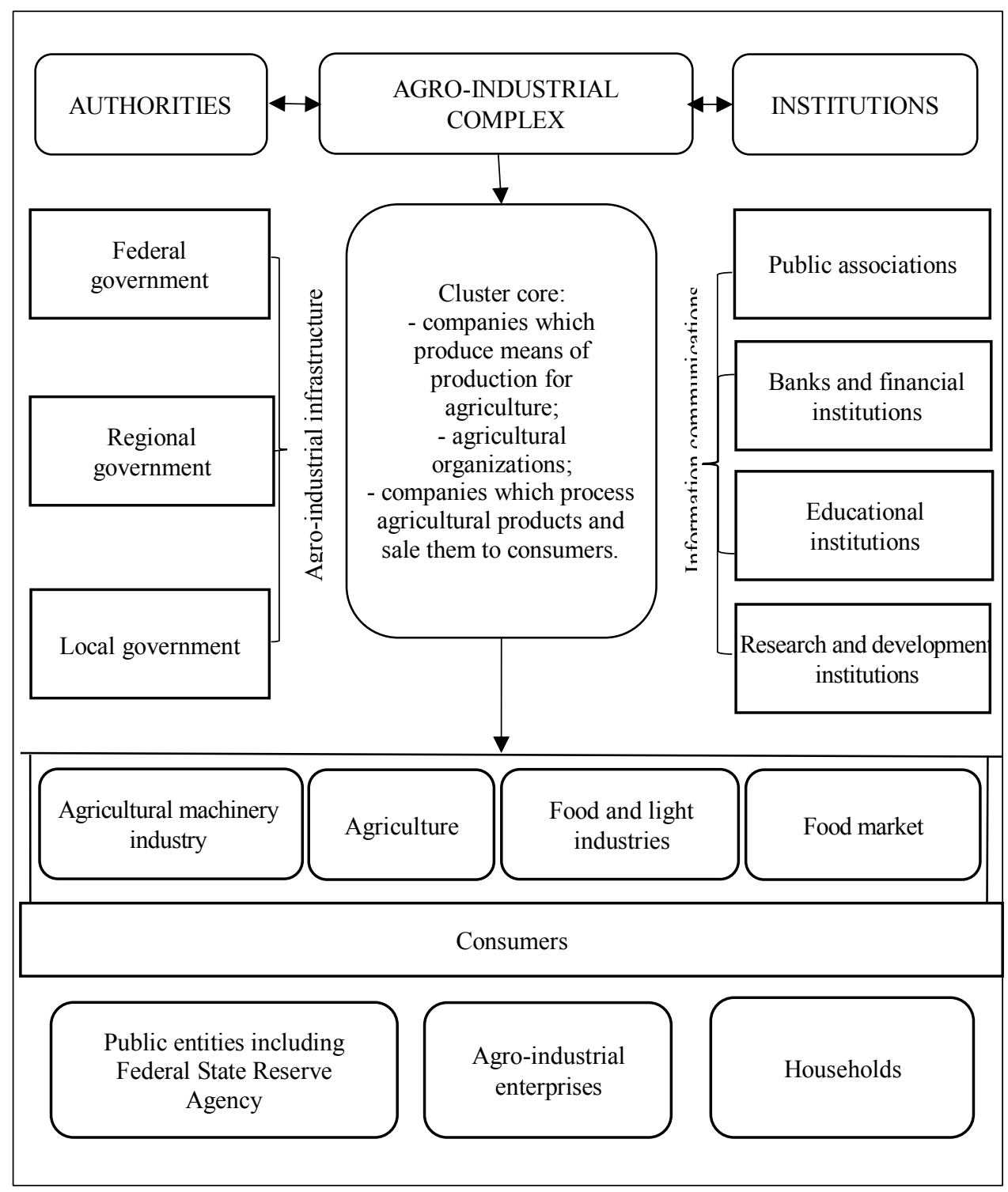

Fig. 1. The structure of marketing cluster in the agro-industrial complex.

The marketing cluster in the agro-industrial complex involves not so much the territorial association, but the creation of a closed-loop production with maximum processing of agricultural products and the possibility to integrate enterprises from different regions. At the same time, the marketing cluster should include alternative marketing relations within the cluster.

Thus, the formation of marketing clusters can be a viable strategy for agro-industrial complex efficient development. Cluster development will help to get a complete configuration of the process of organization and management of food production in the context of rationality of technical, technological and financial issues related to production, logistics, processing and sales of agricultural products. This will provide prospects for the country's development considering its integration into the world economy. 


\section{Conclusion}

Russia has serious difficulties in competing with some countries, especially developed ones and, above all, European countries, in production of such agricultural products as sugar, pork and cattle meat, rareripes. After all, the costs of their production by domestic agricultural producers will always exceed the costs of their production in other countries. The reason lies in low productivity, yield, unsustainable production technologies and so on [13, 14].

In that context, the cluster form of integrated structures, which is still rather poorly developed in Russia, can help to increase the competitiveness of agro-industrial enterprises and ensure food and economic security of both the whole country and its regions [15].

Nevertheless, despite the increasing interest of thinkers and practitioners in cluster opportunities, the number of clusters in the Russian economy is low due to such reasons as:

- the lack of a legal framework regulating the issues of cluster formation and operation;

- the need for proactive state policy to ensure a unified approach and coordinated work of executive authorities of various levels for initiation, development and formation of clusters; the need of legal, organizational and financial support for cluster initiatives;

- insufficient information support in the field of formation algorithm and functioning results of established clusters among professionals, entrepreneurs, executive authorities and public organizations;

- high level of business and property concentration, monopolization of certain activities, production and trade, low level of economic competition and competitiveness in several important economic indicators;

- poor institutional protection of property rights (including against raiding), low level of healthy competition, high degree of corruption;

- lack of awareness of small and medium-sized businesses of clustering benefits, fear of mergers and acquisitions.

Thus, the formation of marketing clusters in the agro-industrial complex could serve as an impetus for the development of not only agricultural production in Russia, but also processing sector, along with the improvement of quality and competitiveness of the entire industry.

\section{References}

1. Y. Vertakova, I. Risin, Procedia Economics and Finance 27, 538-547 (2015) doi.org/10.1016/S2212-5671(15)01030-8

2. E. Kharchenko, E. Alpeeva, O. Ovcharova, Procedia Economics and Finance 14, 313319 (2014) doi.org/10.1016/S2212-5671(14)00718-7

3. A. Chernaya, M. Kabanenko, S. Ugrimova, Conf. Series: Earth and Environmental Science 274 (2019) doi:10.1088/1755-1315/274/1/012073

4. I. Ablaev, Procedia Economics and Finance 24, 3-12 (2015) doi.org/10.1016/S22125671(15)00605-X

5. M. Khayrullina, Procedia Economics and Finance 16, 88-94 doi.org/10.1016/S2212-5671(14)00778-3

6. S. Sosnovskikh, Russian Journal of Economics 3(2), 174-199 (2017) doi.org/10.1016/j.ruje.2017.06.004

7. G. Ryazanova, IFAC-PapersOnLine, 52(25), 225-230 doi.org/10.1016/j.ifacol.2019.12.477

8. Y. Vertakova, Y. Polozhentseva, N. Trusova, G. Zhurova, Procedia Economics and Finance 23, 321-328 (2015) doi.org/10.1016/S2212-5671(15)00559-6 
9. G. Grigoreva, M. Kabanenko, N. Andreeva, IOP Conf. Series: Earth and Environmental Science 274, 012074 (2019) doi:10.1088/1755-1315/274/1/012074

10. Y. Griewald, Journal of Rural Studies 47(A), 21-30 (2016) doi.org/10.1016/j.jrurstud.2016.07.010

11. D. Loginov, E. Karanina, Procedia Engineering 165, 972-979 (2016) doi.org/10.1016/j.proeng.2016.11.808

12. V. Uzun, N. Shagaida, Z. Lerman, Land Use Policy 83, 475-487 (2019) doi.org/10.1016/j.landusepol.2019.02.018

13. M. Svanidze, L. Götz, Global Food Security 21, 60-68 (2019) doi.org/10.1016/j.gfs.2019.07.004

14. S. Wegren, Journal of Eurasian Studies 3(2), 193-202 (2012) doi.org/10.1016/j.euras.2012.03.010

15. V. Glinskiy, L. Serga, M. Alekseev, N. Samotoy, E. Simonova, Procedia Manufacturing 21, 838-845 (2018) doi.org/10.1016/j.promfg.2018.02.191 